\title{
DIVERSITY OF BRYOPHYTES IN SHOW CAVES IN SLOVENIA AND RELATION TO LIGHT INTENSITIES
}

\section{DIVERZITETA MAHOV V TURISTIČNIH JAMAH V SLOVENIJI IN POVEZAVA Z INTENZITETO OSVETLJEVANJA}

\author{
Janez MULEC ${ }^{1} \&$ Svatava KUBEŠOVÁ ${ }^{2}$
}

\begin{abstract}
UDC 582.32:551.442(497.4) Janez Mulec \& Svatava Kubešová: Diversity of bryophytes in show caves in Slovenia and relation to light intensities

In subterranean environments phototrophic organisms can grow only in the proximity of light sources. In a study from eight Slovenian show caves: Črna jama, Kostanjeviška jama, Krška jama, Pekel pri Zalogu, Pivka jama, Postojnska jama, Škocjanske jame, Županova jama and two mines, Idrija mercury mine and Mežica lead and zinc mine, equipped for tourist visits, 37 taxa of Bryophyta and Pteridophyta were identified. The most frequent organisms were mosses Amblystegium serpens, Brachythecium sp., Eucladium verticillatum and Fissidens taxifolius. The highest diversity of bryophytes was recorded in Mežica mine with 16 identified taxa where lamps are on continuously. Bryophytes were collected at wide range of photosynthetic photon flux densities (PPFD) from 0.2 to $530.0 \mu \mathrm{mol}$ photons $/ \mathrm{m}^{2} / \mathrm{s}$. Eucladium verticillatum had the highest span of PPFDs, ranging from 1.4 to $530.0 \mu \mathrm{mol}$ photons $/ \mathrm{m}^{2} / \mathrm{s}$. Bryophytes compensate for low PPFD with longer exposure to light irradiance. Cratoneuron filicinum identified in Mežica mine developed sporophytes at 2.1 and $2.4 \mu \mathrm{mol}$ photons $/ \mathrm{m}^{2} / \mathrm{s}$, in Postojnska jama Brachythecium salebrosum developed sporophytes at $4.7 \mu \mathrm{mol}$ photons $/ \mathrm{m}^{2} / \mathrm{s}$. Recolonization of lampenflora in show caves where bleach is applied to prevent its growth is still successful at sites that are exposed to long periods of irradiance and high PPFDs.
\end{abstract}

Keywords: caves, bryophytes, lampenflora, PPFD, Slovenia.
Izvleček UDK 582.32:551.442(497.4)

Janez Mulec \& Svatava Kubešová: Diverziteta mahov v turističnih jamah $v$ Sloveniji in povezava $z$ intenziteto osvetljevanja

$\mathrm{V}$ podzemelju fototrofni organizmi lahko uspevajo zgolj $\mathrm{v}$ bližini vira svetlobe. $\mathrm{V}$ raziskavi, ki je vključevala vzorce iz osmih turističnih jam v Sloveniji, iz Črne jame, Kostanjeviške jame, Krške jame, jame Pekel pri Zalogu, Pivke jame, Postojnske jame, Škocjanskih jam, Županove jame in dveh rudnikov, Rudnika živega srebra Idrija in Rudnika svinca in cinka Mežica, ki sta opremljena za turistični obisk, smo identificirali celokupno 37 taksonov mahov in praproti. Najpogosteje zastopani so bili mahovi Amblystegium serpens, Brachythecium sp., Eucladium verticillatum in Fissidens taxifolius. V predelu Rudnika Mežica, kjer so luči stalno prižgane, je bila s 16 taksoni ugotovljena največja pestrost mahov. Mahove smo vzorčevali pri zelo različnih gostotah toka fotonov, potrebnih za fotosintezo (PPFD), in sicer v razponu od 0,2 do $530,0 \mu \mathrm{mol}$ fotonov $/ \mathrm{m}^{2} / \mathrm{s}$. Eucladium verticillatum je imel največji razpon PPFD od 1,4 do $530,0 \mu \mathrm{mol}$ fotonov $/ \mathrm{m}^{2} / \mathrm{s}$. Mahovi kompenzirajo nizke vrednosti PPFD z daljšo izpostavljenostjo svetlobnemu osvetljevanju. V Rudniku Mežica je bil identificiran mah Cratoneuron filicinum $\mathrm{z}$ razvitim sporofitom pri vrednostih 2,1 in $2,4 \mu \mathrm{mol}$ fotonov $/ \mathrm{m}^{2} / \mathrm{s}$, v Postojnski jami pa pri $4,7 \mu \mathrm{mol}$ fotonov $/ \mathrm{m}^{2} / \mathrm{s}$ Brachythecium salebrosum s prav tako razvitim sporofitom. $\mathrm{Na}$ mestih $\mathrm{v}$ turističnih jamah, ki so izpostavljena daljšemu osvetljevanju in višjim vrednostim PPFD, in kjer za zatiranje lampenflore uporabljajo belilna sredstva, je njena ponovna kolonizacija vseeno uspešna.

Ključne besede: jame, mahovi, lampenflora, PPFD, Slovenija.

\footnotetext{
${ }^{1}$ Karst Research Institute, Scientific Research Centre of the Slovenian Academy of Sciences and Arts, Titov trg 2, SI-6230 Postojna, Slovenia, e-mail: janez.mulec@guest.arnes.si

${ }^{2}$ Moravian Museum, Department of Botany, Hviezdoslavova 29a, CZ-62700 Brno, Czech Republic, e-mail: skubesova@mzm.cz

Received/Prejeto: 26.03.2010
} 


\section{INTRODUCTION}

To present underground features and to attract visitors, more and more show caves in many areas around the globe are being equipped with electric lighting. In show caves with artificial illumination phototrophs do not grow only at cave entrances where they are exposed to natural sunlight, but also deep in the underground in the vicinity of lamps. Different rocky surfaces, sediments and artificial materials around lamps become colonized by phototrophs. This community of phototrophs named lampenflora is composed of cyanobacteria, algae, bryophytes and ferns - usually prothalli. A prothallus is a short-lived fern haploid structure which forms from a spore with numerous rhizoids growing underneath. Only exceptionally shoots of flowering plants can be recorded deep in the underground (Martinčič et al. 1981; Kubešová 2001). Lampenflora organisms are usually typical surface species (Dobat 1998; Mulec 2008). Some cyanobacteria and microalgae from this community can survive even at photon flux densities lower than their photosynthetic compensation point. At the cave temperature the light saturation point of these organisms is quickly reached (Mulec et al. 2008). Existence of lampenflora deep in show caves indicates constant and efficient transport of viable plant propagules from outside caves by air cur- rents, water flow, or by animals and humans (Dobat 1970; Rajczy 1989).

Soon after installation of lighting system in a cave the question arises how to prevent growth of this alien vegetation. The best way in controlling lampenflora growth is still the physical approach, e.g., proper selection of time-limited irradiation, reduction of light intensity, separation of lighting of tourist trails from other underground inventory, using light spectrum which does not support photosynthesis, and well-considered illuminated surfaces (Rajczy 1989; Olson 2002; Zelinka et al. 2002; Mulec \& Kosi 2009). To avoid further infestation of lampenflora its successful removal is a crucial step. However, in some caves lampenflora is preserved as a tourist attraction. Nevertheless, lampenflora in caves shows that natural cave conditions are disturbed which enables invaders from the surface to be more competitive than the originally present troglomorphic organisms (Mulec \& Kosi 2009).

In Slovenia cave tourism has a long tradition, with one of the oldest documented show caves in the world - Vilenica from 1633 and world-famous Postojnska jama which is equipped with electric lightening since 1889 (Shaw 2003). The occurrence of plants growing around

Tab. 1: Caves and mines with lampenflora in Slovenia with data on tourist management and light irradiation of sampled sites

\begin{tabular}{|c|c|c|c|c|c|c|c|c|c|}
\hline \multirow[t]{2}{*}{ Cave/Mine } & \multirow[t]{2}{*}{ Lithology } & \multirow{2}{*}{$\begin{array}{l}\text { Altitude } \\
\text { (m) }\end{array}$} & \multirow{2}{*}{$\begin{array}{c}\text { Annual } \\
\text { number of } \\
\text { visitors }\end{array}$} & \multirow{2}{*}{$\begin{array}{c}\text { Electric } \\
\text { equipment }\end{array}$} & \multirow{2}{*}{$\begin{array}{c}\text { Use of } \\
\text { herbicides }\end{array}$} & \multirow{2}{*}{$\begin{array}{c}\text { Annual } \\
\text { illumination } \\
\text { (hrs/sector) }\end{array}$} & \multicolumn{3}{|c|}{ PPFD ( $\mu \mathrm{mol}$ photons $/ \mathrm{m}^{2} / \mathrm{s}$ ) } \\
\hline & & & & & & & $A V G \pm S D$ & Min & $\operatorname{Max}$ \\
\hline Črna jama & Cretaceous limestones & 540 & 3,000 & 1929 & + & $>70$ & 130 & 130 & 130 \\
\hline $\begin{array}{l}\text { Kostanjeviška } \\
\text { jama }\end{array}$ & $\begin{array}{l}\text { Cretaceous limestones, } \\
\text { dolomites }\end{array}$ & 170 & 10,000 & 1970 & - & $>60$ & $71 \pm 53$ & 9 & 213 \\
\hline Krška jama & $\begin{array}{l}\text { Jurassic and Triassic } \\
\text { limestones, dolomites }\end{array}$ & 540 & 10,000 & 1995 & - & $>100$ & $56 \pm 40$ & 7 & 138 \\
\hline $\begin{array}{l}\text { Pekel pri } \\
\text { Zalogu }\end{array}$ & $\begin{array}{l}\text { Triassic limestones, } \\
\text { dolomites }\end{array}$ & 314 & 20,000 & $\begin{array}{l}1972,1976 \\
1997^{b}\end{array}$ & + & $>100$ & $9 \pm 16$ & 1 & 59 \\
\hline Pivka jama & Cretaceous limestones & 540 & 3,000 & 1929 & + & $>70$ & $29 \pm 23$ & 5 & 51 \\
\hline $\begin{array}{l}\text { Postojnska } \\
\text { jama }\end{array}$ & Cretaceous limestones & 529 & 500,000 & 1884 & ++ & 1,000 & $110 \pm 124$ & 5 & 530 \\
\hline $\begin{array}{l}\text { Škocjanske } \\
\text { jame }\end{array}$ & $\begin{array}{l}\text { Cretaceous and } \\
\text { Paleogene limestones }\end{array}$ & 425 & 90,000 & 1959 & - & 477 & $51 \pm 64$ & 2 & 200 \\
\hline $\begin{array}{l}\text { Županova } \\
\text { jama }\end{array}$ & Jurassic limestones & 468 & 10,000 & 1937 & - & $>80$ & $74 \pm 54$ & 17 & 173 \\
\hline $\begin{array}{l}\text { Idrija, mercury } \\
\text { mine }\end{array}$ & $\begin{array}{l}\text { Permocarbonian shales, } \\
\text { dolomites }\end{array}$ & 330 & 25,000 & 1994 & + & $>214$ & $5 \pm 6$ & 1 & 18 \\
\hline $\begin{array}{l}\text { Mežica, lead } \\
\text { and zinc mine }\end{array}$ & $\begin{array}{l}\text { Carnian limestones, } \\
\text { Triassic dolomites, } \\
\text { shales }\end{array}$ & 500 & $17,000^{\mathrm{a}}$ & $2000^{a}$ & - & 8.760 & $0.9 \pm 0.8$ & 0.2 & 2.7 \\
\hline
\end{tabular}

${ }^{a}$ no tourist visit in the area with lampenflora

${ }^{\mathrm{b}}$ successive electrification

++ regular, + occasional, - never 
lamps in Postojnska jama was addressed as early as 1941 (Morton 1941). Because of long-term experience with lampenflora growth in Slovenian caves (Tab. 1) the objectives of this study were to ascertain how different irradiance levels influence bryophytes distribution and to compare floristic composition with previous studies (e.g., Martinčič et al. 1981). In early phases of lampenflora succession cyanobacteria and microalgae play a more important role (Mulec et al. 2008). In this paper only Bryophytes and Pteridophytes are studied, which usually appear later in species succession.

\section{MATERIAL AND METHODS}

Eight show caves, Črna jama, Postojnska jama, Kostanjeviška jama, Krška jama, Pekel pri Zalogu, Pivka jama, Škocjanske jame, Županova jama and two mines equipped for tourist visit (Idrija mercury mine, Mežica lead and zinc mine) were screened for the presence of Bryophyte lampenflora (Fig. 1). In comparision to the previous studies (Morton 1941; Latzel 1942; Grom 1961, 1962; Dobat 1973; Martinčič et al. 1981) few new caves were added to the list of show caves with lampenflora (Tab. 1).

In show caves tourists observe various natural karstological features, e.g., flowstone formations and underground river flows, while in mines they learn about history of mining and exploitation of natural resources that is why the illuminated objects in caves and mines usually differ. In show caves and mines where lampenflora was sampled, lamps are periodically turned on due to tourist visits or maintenance of the tourist infrastructure. Time when caves are exposed to lighting varies; the longest period of illumination in caves is in Postojnska jama and Škocjanske jame. In Mežica lead and zinc mine at the sampling location, which is not visited by tourists, lamps are on 24 hours due to constant monitoring of the underground water flow. Bryophytes generally grow on restricted illuminated surfaces around lamps in the underground, except in Mežica mine where around two lamps they covered approximately $15 \mathrm{~m}^{2}$ of rocky surface (Fig. 4D). Other surfaces in Mežica mine were not colonized with lampenflora. Caves experience different intensities of tourist visits of which Postojnska jama has the longest tradition and highest number of tourists (Tab. 1). The history of lampenflora study and control is different for each cave, for example problem with plants inside Postojnska jama has been reported already by Morton (1941). In Postojnska jama bleach was is used to kill lampenflora every second year.

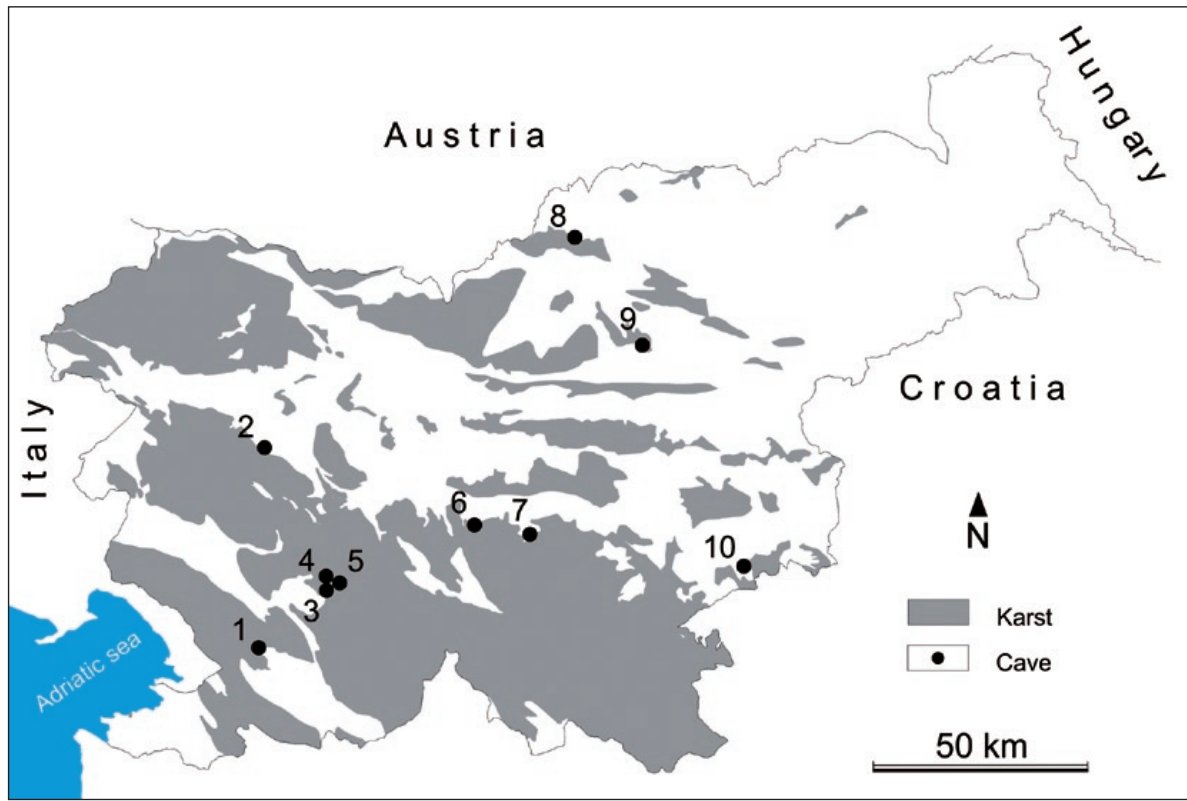

Fig. 1: Geographical location of studied show caves and mines in Slovenia (1-Škocjanske jame, 2-Idrija mine, 3-Postojnska jama, 4-Pivka jama, 5-Črna jama, 6-Županova jama, 7-Krška jama, 8-Mežica mine, 9-Pekel pri Zalogu, 10-Kostanjeviška jama).
Sampling was performed between $23^{\text {rd }}$ and $28^{\text {th }}$ of March 2008. When possible the same sites were selected as for the study of cyanobacteria and algae of lampenflora communities in 2003 (Mulec et al. 2008). Prior to taking specimens photosynthetically active radiation at sites was quantified as $\mu \mathrm{mol}$ photons $/ \mathrm{m}^{2} / \mathrm{s}$ using a LICOR LI-1000 DataLogger (USA), which is a measure of photosynthetic photon flux density (PPFD). If various plants were observed around a selected lamp several specimens were sampled at different distances. After collection field material was sorted and determined under a binocular microscope and a light 
microscope (Olympus SZ40 and Olympus CX31, respectively). Identification followed determination keys after
Hradílek 1994, Hedenäs 2003 and Frey et al. 2006. The nomenclature is according to Frey et al. 2006.

\section{RESULTS AND DISCUSSION}

From eight caves and two mines equipped with electric illumination in this study 37 taxa of Bryophyta and Pteridophyta were identified. The most frequent organisms identified in studied Slovenian caves and mines were Amblystegium serpens (frequency in all studied caves and mines was 0.60), Brachythecium sp. (0.50), Eucladium verticillatum (0.50) and Fissidens taxifolius (0.50) (Tab. 2).

The highest number of different phototrophic taxa were identified in Mežica lead and zinc mine (16) with the highest frequency of Cratoneuron filicinum (0.57), Eucladium verticillatum (0.19) and Platyhypnidium riparioides (0.14) followed by jama Pekel with 14 organisms (Eucladium verticillatum, 0.43, Fissidens cf. bryoides, 0.36, Taxiphyllum cf. wissgrillii, 0.21), Kostanjeviška jama with 13 taxa (Cratoneuron filicinum, 0.35, Fissidens cf. bryoides, 0.35, and Rhynchostegium murale, 0.18). Lower taxa numbers were recorded in Postojnska jama with 9 taxa (Eucladium verticillatum, 0.94, Rhynchostegium murale, 0.17, Bryum sp., 0.17), Škocjanske jame with 8 taxa (Eucladium verticillatum, 0.91, Weissia sp., 0.27), Idrija mercury mine with 7 bryophytes (Amblystegium serpens, 0.38, Brachythecium sp., 0.38), Županova jama with 8 bryophytes (Brachythecium sp., 0.33, Amblystegium serpens, 0.22), Krška jama with 6 taxa (Amblystegium serpens, 0.40, Fissidens sp., 0.30), Pivka jama with 3 bryophytes Rhynchostegium murale (1.0), and Črna jama with one bryophyte Orthothecium intricatum (1.0).
Based on previous studies floristically the most diverse was lampenflora from Postojnska jama with 30 identified taxa (Tab. 2). In this study we identified only 9 taxa what can be attributed to regular removal of lampen flora using bleach. A similar decrease in taxa linked to chemical removal of lampenflora and reduction of light intensity was experienced also in show caves in the Czech Republic (Kubešová 2001, 2004). Regular removal of lampenflora patches in Postojnska jama is likely the reason for lower diversity of cyanobacteria and algae compared to other caves (Mulec et al. 2008). For example previous screening of lampenflora organisms in Postojnska jama revealed out of 13 sampled sites (9 cyanobacterial and 8 algal taxa) only three colonized by mosses and ferns (one moss and one fern species) (Mulec 2005).

The highest diversity was found in Mežica mine with 16 identified taxa indicating that lighting scheme was the most favourable for mosses (Tab. 1). Martinčič and coworkers described jama Pekel as "the greenest cave" in Slovenia where they identified 21 taxa of Bryophyta and Pteridophyta (Martinčič et al. 1981). In this study we found only 14 taxa in the cave. Lower number of mosses and ferns from jama Pekel compared to older study can be explained with changed lamps in the cave in the last years which emit lower PPFDs.

In our study lampenflora communities comprised mosses and ferns, but no liverworts were identified. In previous studies they were recorded in jama Pekel and
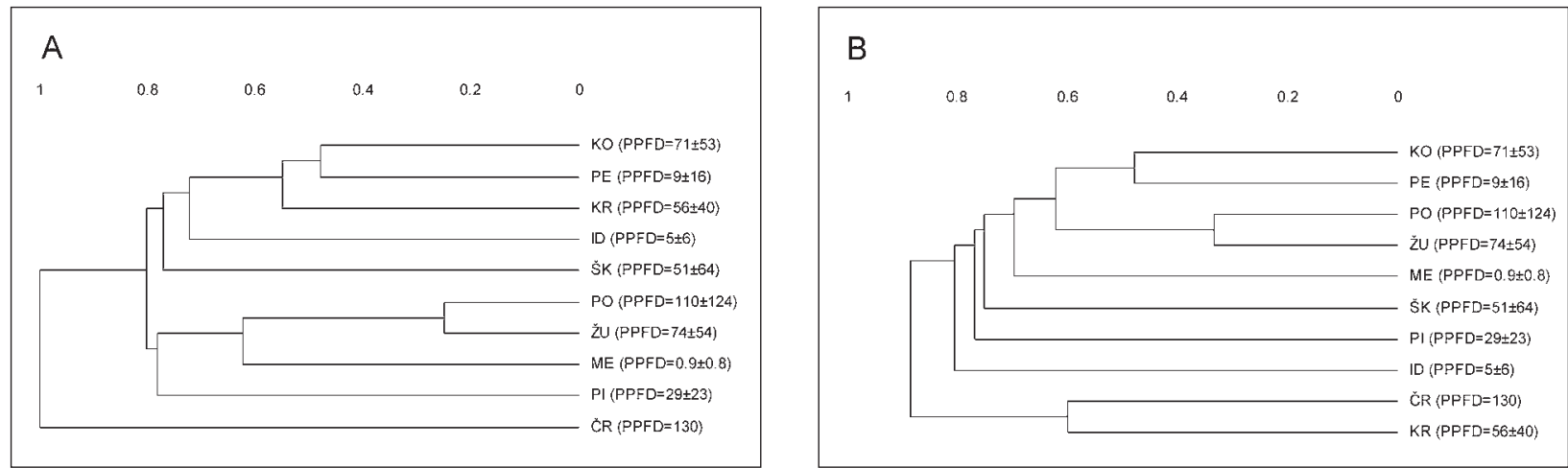

Fig. 2: Bray-Curtis dissimilarity index of lampenflora in Slovenian show caves; A-analysis based on bryophytes, B-analysis based on identified bryophytes and pteridophytes (ČR-Črna jama, ID-Mercury mine in Idrija, KO-Kostanjeviška jama, KR-Krška jama, ME-Lead and zinc mine Mežica, PE-jama Pekel, PI-Pivka jama, PO-Postojnska jama, ŠK-Škocjanske jame, ŽU-Županova jama, PPFD expressed in $\mu \mathrm{mol}$ photons $/ \mathrm{m}^{2} / \mathrm{s}$ per cave). 
Table 2: Bryophytes and pteridophytes in Slovenian show caves (ČR-Črna jama, ID-Mercury mine in Idrija, KO-Kostanjeviška jama, KR-Krška jama, ME-Lead and zinc mine Mežica, PE-jama Pekel, PI-Pivka jama, PO-Postojnska jama, ŠK-Škocjanske jame, ŽU-Županova jama, I-previous studies, II-this study)

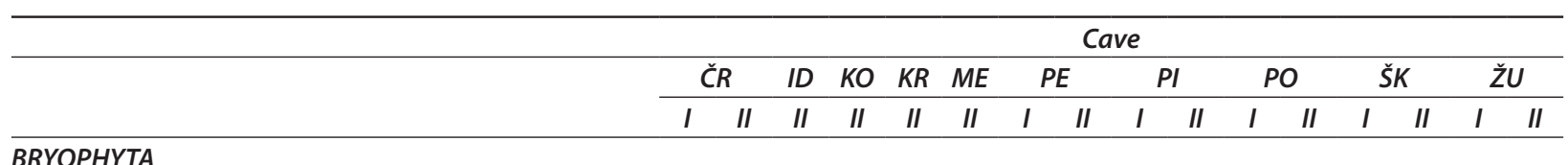

\section{BRYOPHYTA}

Liverworts

Leiocolea bantriensis (Hook.) Jörg.

Pellia epiphylla (L.) Corda

\section{Mosses}

Amblystegium sp. Schimp.

Amblystegium subtile (Hedw.) Schimp.

Amblystegium serpens subsp. juratzkanum (Schimp.)

Ren. \& Card.

Amblystegium serpens (Hedw.) Schimp.

Amblystegium varium (Hedw.) Lindb.

Barbula unguiculata Hedw.

Brachythecium sp. Schimp.

Brachythecium cf. campestre (Müll. Hal.) Schimp.

Brachythecium mildeanum (Schimp.) Schimp.

Brachythecium cf. plumosum (Hedw.) Schimp.

Brachythecium cf. rivulare Schimp.

Brachythecium rutabulum (Hedw.) Schimp.

Brachythecium cf. rutabulum (Hedw.) Schimp.

Brachythecium salebrosum (Hoffm. ex F. Weber \& D.

Mohr) Schimp.

Brachythecium velutinum (Hedw.) Schimp.

Brachythecium cf. velutinum (Hedw.) Schimp.

Brachythecium velutinum var. spelaeorum Latzel

Bryoerythrophyllum sp. P. C. Chen

Bryoerythrophyllum recurvirostrum (Hedw.) P. C. Chen

Bryum sp. Hedw.

Campylium calcareum Crundw. \& Nyholm

Cirriphyllum tommasinii (Sendt. ex Boulay) Grout

Cratoneuron filicinum (Hedw.) Spruce

Dicranella heteromalla (Hedw.) Schimp.

Didymodon rigidulus Hedw.

Didymodon vinealis (Brid.) R. H. Zander

Encalypta sp. Hedw.

Encalypta streptocarpa Hedw.

Encalypta vulgaris var. obtusa Nees. \& Hornsch.

Eucladium verticillatum (With.) Bruch \& Schimp.

Eucladium verticillatum (With.) Bruch \& Schimp. subsp.

verticillatum

Eucladium verticillatum subsp. styriacum (Glow.) J. J.

Amann

Eurhynchium sp. Schimp.

Fissidens sp. Hedw.

Fissidens bambergeri Schimp. ex Milde

Fissidens bryoides Hedw.

Fissidens cf. bryoides Hedw.

Fissidens dubius P. Beauv.

\begin{tabular}{|c|c|c|c|c|c|c|c|c|c|c|c|c|c|}
\hline+ & + & + & . & $\cdot$ & + & + & + & + & $\cdot$ & r & . & . & + \\
\hline . & . & . & . & . & . & + & . & . & . & $\cdot$ & . & . & . \\
\hline . & . & . & . & . & . & . & . & + & . & & . & . & . \\
\hline+ & + & . & + & + & + & . & . & . & . & . & . & . & + \\
\hline . & . & . & . & + & . & . & . & . & . & . & . & . & . \\
\hline . & . & . & . & . & . & . & . & + & . & . & . & . & . \\
\hline . & . & . & . & . & . & . & . & + & . & . & . & . & . \\
\hline+ & . & . & . & . & . & . & . & . & . & . & . & . & . \\
\hline . & . & . & . & . & . & . & . & + & . & . & . & . & . \\
\hline . & + & . & . & . & . & . & . & . & . & - & - & . & . \\
\hline . & . & . & $\cdot$ & . & . & . & . & $\cdot$ & + & . & • & . & . \\
\hline . & + & + & . & . & + & . & . & + & . & . & . & . & . \\
\hline . & . & . & . & . & . & . & . & . & + & . & . & . & . \\
\hline . & . & . & . & . & . & . & . & + & . & . & . & . & . \\
\hline . & . & . & + & . & . & . & . & . & . & . & . & . & . \\
\hline . & . & . & . & . & . & . & . & + & . & . & . & . & . \\
\hline . & . & . & + & . & . & . & . & . & + & - & - & . & + \\
\hline . & + & . & . & . & . & . & . & + & . & . & + & . & . \\
\hline . & . & . & . & + & . & . & . & . & . & . & . & . & . \\
\hline . & + & . & + & + & + & . & . & . & . & . & . & . & + \\
\hline . & + & . & . & . & . & . & . & . & . & . & . & . & . \\
\hline . & . & . & . & . & . & . & . & + & . & . & . & . & 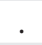 \\
\hline . & . & . & . & . & . & . & . & + & . & . & . & + & . \\
\hline . & . & . & . & . & . & . & . & . & . & . & . & . & . \\
\hline . & . & . & + & + & . & . & . & . & . & . & . & . & . \\
\hline . & . & . & . & . & . & . & . & + & . & . & . & . & . \\
\hline . & . & . & + & . & + & . & . & . & + & - & + & . & + \\
\hline . & . & . & . & + & . & . & . & + & . & . & . & $\cdot$ & . \\
\hline . & $\cdot$ & . & . & + & . & $\cdot$ & . & + & $\cdot$ & • & . & . & . \\
\hline . & . & . & + & . & . & . & . & . & . & . & . & . & . \\
\hline . & + & + & . & . & . & . & . & . & . & - & + & . & . \\
\hline$\cdot$ & . & . & . & . & . & . & . & + & . & . & . & . & . \\
\hline . & . & . & . & + & . & . & . & + & . & + & . & + & . \\
\hline . & + & + & . & . & + & . & . & . & . & . & . & . & . \\
\hline+ & . & . & 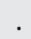 & + & + & + & 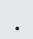 & + & . & . & + & . & \\
\hline
\end{tabular}




\begin{tabular}{|c|c|c|c|c|c|c|c|c|c|c|c|c|c|c|c|c|}
\hline & \multicolumn{16}{|c|}{ Cave } \\
\hline & \multicolumn{2}{|c|}{$\check{C} R$} & \multirow{2}{*}{$\frac{I D}{I I}$} & \multirow{2}{*}{$\frac{K O}{I I}$} & \multirow{2}{*}{$\frac{K R}{I I}$} & \multirow{2}{*}{$\frac{M E}{I I}$} & \multicolumn{2}{|c|}{$P E$} & \multicolumn{2}{|c|}{$P I$} & \multicolumn{2}{|c|}{$P O$} & \multicolumn{2}{|c|}{$\check{S} K$} & \multicolumn{2}{|c|}{$\ddot{Z} U$} \\
\hline & $I$ & II & & & & & $I$ & II & $I$ & II & $I$ & II & $I$ & II & $I$ & II \\
\hline Funaria hygrometrica Hedw. & . & . & . & . & . & . & . & . & . & . & + & . & . & . & . & . \\
\hline Homomallium incurvatum (Schrad. ex Brid.) Loeske & . & . & . & . & . & . & + & . & . & . & . & . & . & . & . & . \\
\hline Isothecium myosuroides Brid. & . & . & . & . & . & . & + & . & + & . & . & . & . & . & . & . \\
\hline Isothecium myosuroides fo. spelaeum Grom & . & . & . & . & . & . & . & . & . & . & + & . & . & . & . & . \\
\hline Kindbergia praelonga (Hedw.) Ochyra & . & . & . & . & . & . & + & . & . & . & . & . & . & . & . & . \\
\hline Mnium stellare Reichard ex Hedw. & . & . & . & . & . & . & . & + & . & . & . & . & . & . & . & . \\
\hline Orthothecium intricatum (Hartm.) Schimp. & . & + & . & . & . & . & . & . & . & . & . & . & . & . & . & . \\
\hline Oxyrrhynchium schleicheri (R. Hedw.) Röll & + & . & . & . & . & . & . & . & + & . & . & . & . & . & ${ }^{\circ}$ & . \\
\hline Oxyrrhynchium speciosum (Brid.) Warnst. & . & . & . & . & . & . & . & . & . & . & + & . & . & . & . & . \\
\hline Oxyrrhynchium stokesii (Turn.) Podp. & . & . & . & . & . & . & . & . & . & . & + & . & . & . & . & . \\
\hline Oxyrrhynchium hians (Hedw.) Loeske & . & . & . & . & . & . & . & . & . & . & + & . & . & . & . & . \\
\hline Plagiomnium sp. T. J. Kop. & . & . & . & . & . & + & . & . & . & . & . & . & . & . & . & . \\
\hline Plagiomnium affine (Blandow ex Funck) T. J. Kop. & . & . & . & . & . & . & . & . & . & . & + & . & . & . & . & . \\
\hline Plagiomnium cuspidatum (Hedw.) T. J. Kop. & . & . & . & . & . & . & . & . & . & . & + & . & . & . & . & . \\
\hline Plagiomnium rostratum (Schrad.) T. J. Kop. & . & . & . & . & . & + & . & . & . & + & . & . & . & . & . & . \\
\hline Platyhypnidium riparioides (Hedw.) Dixon & . & . & . & . & . & + & . & . & . & . & . & . & . & . & . & . \\
\hline Rhizomnium puntatum (Hedw.) T. J. Kop. & . & . & . & . & . & + & . & . & . & . & . & . & . & . & . & . \\
\hline Rhynchostegiella tenella (Dicks.) Limpr. & . & . & . & + & . & . & + & . & . & . & + & + & + & + & . & + \\
\hline Rhynchostegium murale (Hedw.) Schimp. & . & . & . & + & . & . & . & . & . & + & + & + & . & . & . & + \\
\hline Seligeria donniana (Sm.) Müll. Hal. & . & . & . & . & . & . & + & . & . & . & . & . & . & . & . & . \\
\hline Taxiphyllum wissgrillii (Garov.) Wijk \& Margad. & . & . & . & . & . & . & + & . & + & . & + & . & + & . & . & . \\
\hline Taxiphyllum cf. wissgrillii (Garov.) Wijk \& Margad. & . & . & . & . & . & . & . & + & . & . & . & . & . & . & ${ }^{\circ}$ & . \\
\hline Tortula muralis Hedw. & . & . & + & . & . & . & . & . & . & . & . & . & . & . & . & . \\
\hline Weissia sp. Hedw. & . & . & . & . & . & . & . & . & . & . & . & . & . & + & . & . \\
\hline \multicolumn{17}{|l|}{ PTERIDOPHYTA } \\
\hline Asplenium sp. L. & . & . & . & + & + & . & . & . & . & . & . & . & . & + & . & . \\
\hline Asplenium ruta-muraria $L$. & . & . & . & . & . & . & + & . & . & . & . & . & . & . & . & . \\
\hline Asplenium scolopendrium L. & . & . & . & . & . & . & . & + & . & . & . & . & . & . & . & . \\
\hline Asplenium trichomanes L. & . & . & . & . & . & + & + & + & . & . & + & + & . & . & . & . \\
\hline Cystopteris fragilis (L.) Bernh. & . & . & . & . & . & . & + & . & . & . & . & . & . & . & . & . \\
\hline Cystopteris cf. fragilis (L.) Bernh. & . & . & . & . & . & + & . & . & . & . & . & + & . & . & . & . \\
\hline fern prothallus & . & . & . & . & + & + & . & + & . & . & . & . & . & + & $\cdot$ & . \\
\hline
\end{tabular}

See for references: ČR-I (Martinčič et al. 1981), PE-I (Martinčič et al. 1981), PI-I (Martinčič et al. 1981), PO-I (Morton 1941; Latzel 1942; Grom 1961, 1962; Dobat 1973; Martinčič et al. 1981), ŠK-I (Martinčič et al. 1981), ŽU-I (Martinčič et al. 1981)

Postojnska jama (Tab. 2). This is rather uncommon as in comparable studies in Hungary (Rajczy 1989) and in the Czech Republic (Kubešová 2001) no such plants were recorded. Older studies from show caves from Moravian karst (Czech Republic) indicated presence of liverworts (Vaněčková 1978), but revision of these herbarium specimens demonstrated that they were in fact fern prothalli (Kubešová 2001).

Comparison of lampenflora among 10 caves and mines based on Bray-Curtis dissimilarity index indicated relatively low similarity except between Postojnska jama and Županova jama (Fig. 2). Two statistical analyses using this index were carried out, on communities of bryophytes and on communities of bryophytes and pteridophytes. Results indicated that there is no pattern; different caves have generally different community of plants. Nevertheless, ferns were not frequent dwellers in Slovenian caves, in this study only five taxa were identified. The most frequently recorded were fern prothalli (0.4, Tab. 2). The most apparent group is Postojnska jama-Županova jama. The cluster Postojnska jama and Županova jama had the highest PPFDs at all sites and the lowest dissimilarity index ( 0.33 when bryophytes and pteridophytes were included in the study and 0.25 when only communities of mosses were analyzed). This can be attributed to fast growth of lampenflora in Postojnska jama as a result of high PPFDs despite regular physical removal of lampenflora and in Županova jama to con- 


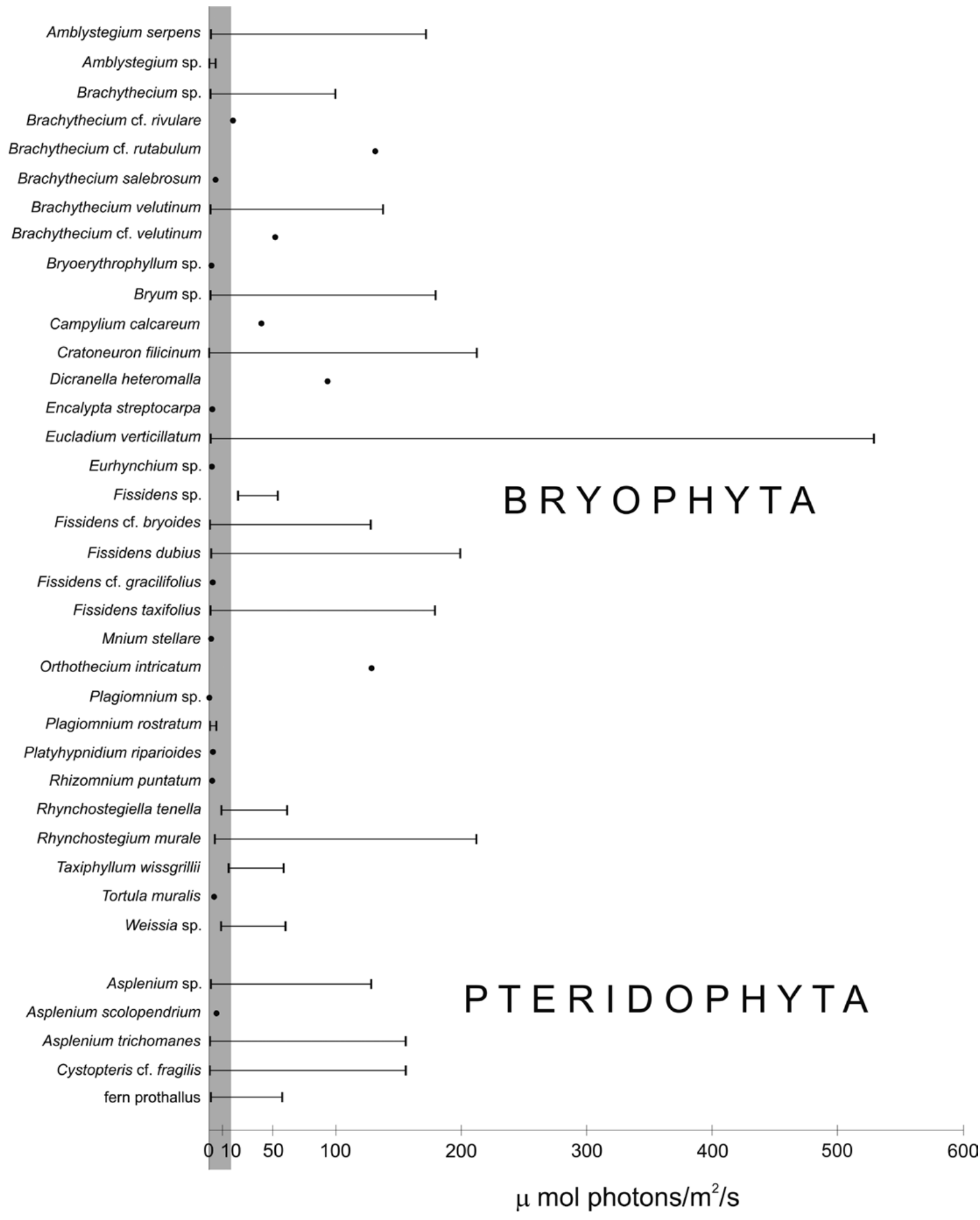

Fig. 3: Span of photosynthetic photon flux density for individual species of mosses and ferns identified in lampenflora community in Slovenian show caves. The second quartile $\left(Q_{2}\right)$ is indicated with grey, i.e. $17 \mu \mathrm{mol}$ photons $/ \mathrm{m}^{2} / \mathrm{s}$. 
stant, but lower PPFDs and no physical removal of plants since establishing of electric illumination (Tab. 1).

Interestingly, lampenflora from Mežica clustered with Postojnska jama-Županova jama group in both analyses; average PPFD was $0.9 \pm 0.8 \mu \mathrm{mol}$ photons/ $\mathrm{m}^{2} / \mathrm{s}$ with lights on $24 \mathrm{hrs}$ per day. This indicates that bryophytes compensated extremely low PPFDs $(0.2$ $-2.7 \mu \mathrm{mol}$ photons $/ \mathrm{m}^{2} / \mathrm{s}$ ) with longer exposition to light irradiation. Furthermore, in Mežica Cratoneuron filicinum was identified with developed sporophyte at photon fluxes at 2.1 and $2.4 \mu \mathrm{mol}$ photons $/ \mathrm{m}^{2} / \mathrm{s}$. In Postojnska jama Brachythecium salebrosum was identified with fully developed sporophyte at PPFD of $4.7 \mu \mathrm{mol}$ photons $/ \mathrm{m}^{2} / \mathrm{s}$ (Fig. 4A). Low PPFDs at which plants were collected indicate their low light compensation point in caves, equal or higher to the measured values. It is known that in extreme habitats light compensation point of bryophytes is similar to that of algal communities. For example in Antarctic lakes Drepanocladus s.l. had light compensation point of approximately $0.5 \mu \mathrm{mol}$ photons $/ \mathrm{m}^{2} / \mathrm{s}$ and Calliergon in shallower water around $2.9 \mu \mathrm{mol}$ photons $/ \mathrm{m}^{2} / \mathrm{s}$ (Glime 2007).

Communities of mosses from Pivka jama and Črna jama were not diverse and were represented by only three and one species, respectively. In these two caves development of moss lampenflora was still in initial phase, and as in 2003 no bryophytes were observed there (Mulec 2005).
Some bryophytes are able to grow over a relatively wide range of light intensities (Glime 2007). Light irradiation at which lampenflora in Slovenian show caves was sampled ranged from 0.2 to $530 \mu \mathrm{mol}$ photons $/ \mathrm{m}^{2} / \mathrm{s}$ (first quartile $\mathrm{Q}_{1}=2$, second quartile $\mathrm{Q}_{2}=17$, third quartile $\mathrm{Q}_{3}=55 \mu \mathrm{mol}$ photons $/ \mathrm{m}^{2} / \mathrm{s}$ ). For some taxa PPFDs at which particular organism was identified varied a lot, especially Eucladium verticillatum (1.4-530.0 $\mu \mathrm{mol}$ photons $\left./ \mathrm{m}^{2} / \mathrm{s}\right)$, Cratoneuron filicinum (0.2-213.0 $\mu \mathrm{mol}$ photons $\left./ \mathrm{m}^{2} / \mathrm{s}\right)$, Rhynchostegium murale (4.7-213.0 $\mu \mathrm{mol}$ photons $\left./ \mathrm{m}^{2} / \mathrm{s}\right)$, Fissidens dubius (1.0$200.0 \mu \mathrm{mol}$ photons $\left./ \mathrm{m}^{2} / \mathrm{s}\right)$, Bryum sp. $(0.9-180.5 \mu \mathrm{mol}$ photons $\left./ \mathrm{m}^{2} / \mathrm{s}\right)$, Fissidens taxifolius (1.4-150.5 $\mu \mathrm{mol}$ photons $\left./ \mathrm{m}^{2} / \mathrm{s}\right)$, Amblystegium serpens (1.0-172.5 $\mu \mathrm{mol}$ photons $\left./ \mathrm{m}^{2} / \mathrm{s}\right)$, Brachythecium velutinum $(0.8-137.7 \mu \mathrm{mol}$ photons $/ \mathrm{m}^{2} / \mathrm{s}$ ), Fissidens cf. bryoides $(0.9-128.9 \mu \mathrm{mol}$ photons $/ \mathrm{m}^{2} / \mathrm{s}$ ), and Brachythecium sp. (0.7-100.3 $\mu \mathrm{mol}$ photons $/ \mathrm{m}^{2} / \mathrm{s}$ ). Among ferns Cystopteris cf. fragilis (0.4$160.0 \mu \mathrm{mol}$ photons $/ \mathrm{m}^{2} / \mathrm{s}$ ), Asplenium trichomanes (0.5$160 \mu \mathrm{mol}$ photons $\left./ \mathrm{m}^{2} / \mathrm{s}\right)$ and Asplenium sp. (2.0-128.9 $\mu \mathrm{mol}$ photons $/ \mathrm{m}^{2} / \mathrm{s}$ ) had the largest span of PPFD at which they were recorded (Fig. 3). In show caves bryophytes were found close to lamps where also temperature is higher due to heat emissions of lights.

Calcite precipitates accumulating on Eucladium verticillatum termed "eucladioliths" (Dalby 1966) can be found in Slovenian caves, too (Fig. 4B, compare with Fig. 4C).

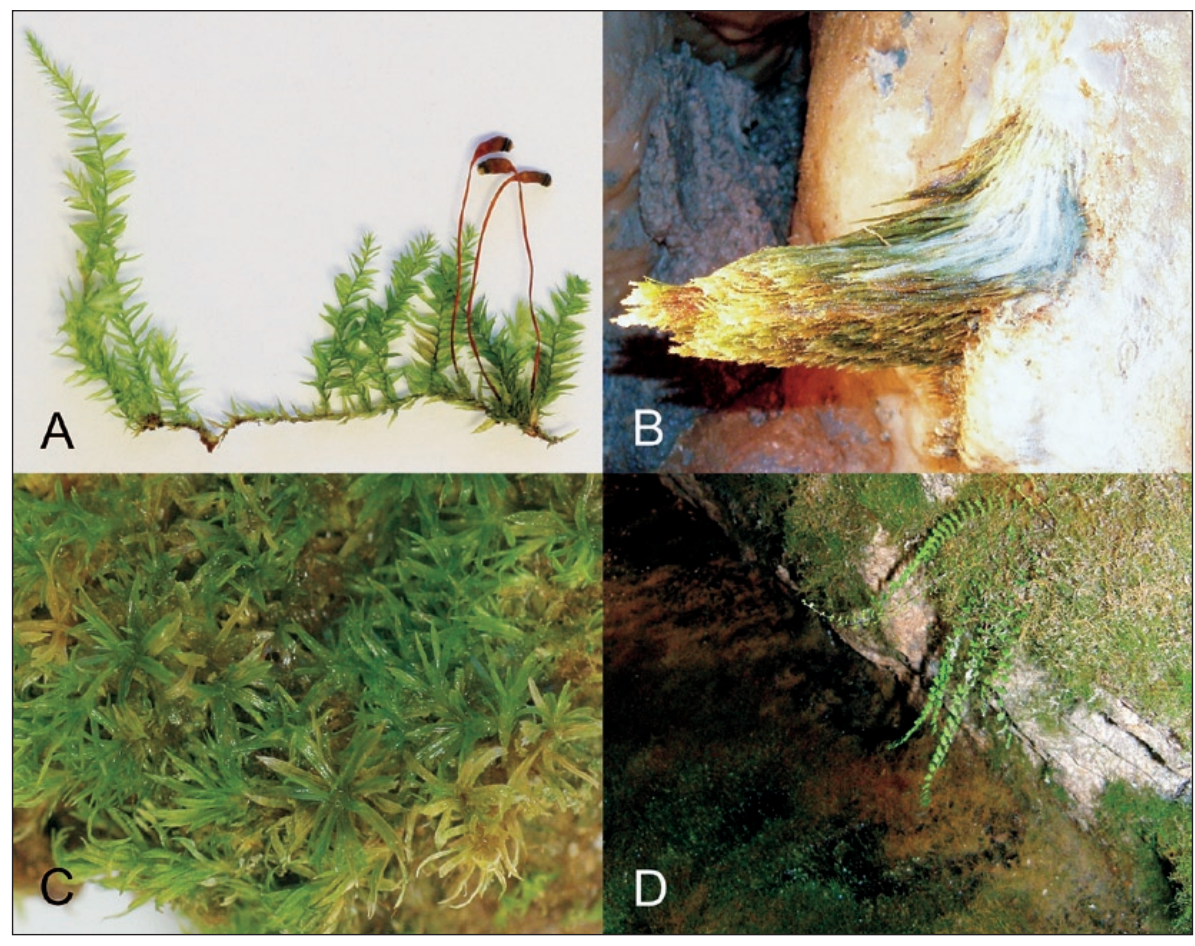

Fig. 4: Bryophytes from lampenflora communities (A-Brachythecium salebrosum with sporophyte from Postojnska jama, B-calcified Eucladium verticillatum, a biogenic plant-shoot speleothem growing towards lit lamp from Postojnska jama, C-Eucladium verticillatum from Škocjanske jame, D-lawn of mosses in Mežica mine, photo: $S$. Kubešová). 


\section{CONCLUSIONS}

In eight Slovenian show caves and two mines equipped with electric illumination 37 taxa of Bryophyta and Pteridophyta were identified. The highest diversity of bryophytes was found in Mežica mine with 16 identified taxa indicating that lighting regime influenced diversity the most.

Light irradiation at which bryophyte lampenflora was recorded started from 0.2 and exceeded $500 \mu \mathrm{mol}$ photons $/ \mathrm{m}^{2} / \mathrm{s}$. For some organisms photosynthetic photon flux density at which particular organism grow, varies considerably. For example, PPFD which enables growth of Eucladium verticillatum ranged from 1.4 to $530.0 \mu \mathrm{mol}$ photons $/ \mathrm{m}^{2} / \mathrm{s}$.
For growth bryophytes compensate low PPFD with longer exposure to light irradiance. In Mežica mine Cratoneuron filicinum was identified with developed sporophyte at 2.1 and $2.4 \mu \mathrm{mol}$ photons $/ \mathrm{m}^{2} / \mathrm{s}$. Similarly in Postojnska jama Brachythecium salebrosum was identified with fully developed sporophyte at $4.7 \mu \mathrm{mol}$ photons $/ \mathrm{m}^{2} / \mathrm{s}$.

Using of highly toxic bleach ( $\mathrm{NaClO})$ which effectively kills lampenflora but has only transitory effect in preventing growth without efficient changes of lighting regime and light quality is thus questionable. Recolonization of lampenflora in caves is rather successful at sites which are exposed to long irradiance period and high PPFDs.

\section{ACKNOWLEDGEMENTS}

Authors are grateful to caves and mines management, particularly to: Brane Čuk, Vanja Debevec, Suzana Fajmut Štrucelj, Stanislav Glažar, Marija Kralj, Nataša Lukman, Martina Pišljar and Martina Terglav. We thank to Zbyněk Hradílek for revision of Fissidens specimens. Part of the study was supported under project no. MK00009486201
(Czech Ministry of Culture) and programme Karst research no. P6-0119 (Slovenian Research Agency). The authors are grateful to David C. Culver for helpful comments on an earlier version of the manuscript and revision of the English text.

\section{REFERENCES}

Dalby, D.H., 1966: The growth of plants under reduced light.- Studies in Speleology, 1, 4, 193-203.

Dobat, K., 1970: Considérations sur la végétation cryptogamique des grottes du Jura Souabe (sud-ouest de l'Allemagne).- Annales de Spéléologie, 25, 4, 872907.

Dobat, K., 1973: Ein Beitrag zur Eingangs-, Lampen- und Pilzflora der Postojnska jama ("Adelsberger Grotte" bei Postojna, Jugoslawien).- Razprave, Slovenska akademija znanosti in umetnosti, 16, 2, 123-143.

Dobat, K., 1998: Flore de la lumiére artificiélle (lampenflora-maladie verte).- In: Juberthie, C. \& V. Decu (eds.) Encyclopaedia biospeleologica, Tome 2. Société de Biospéologie, pp. 1325-1335, Moulis-Bucarest.

Frey, W., Frahm, J.P., Fischer, E. \& W. Lobin, 2006: The liverworts, mosses and ferns of Europe.- Harley Books, pp. 512, Colchester.
Glime, J.M., 2007: Light: the shade plants, Bryophyte ecology, Volume 1, Physiological ecology, Ebook sponsored by Michigan technological university and the International association of bryologist.[Online] Available from: http://www.bryoecol.mtu. edu/ [Accessed 24 $4^{\text {th }}$ February 2010].

Grom, S., 1961: Jamsko rastlinstvo.- Naše jame, 2, 1-2, 63-68.

Grom, S., 1962: Beitrage zur Moosflora Sloweniens (Jugoslawien) 2.- Nova Hedwigia, 5, 3-4, 477-485.

Hedenäs, L., 2003: The European species of the Calliergon-Scorpidium-Drepanocladus complex, including some related or similar species.- Meylania, 28, $1-116$.

Hradílek, Z., 1994: Klíč na učování zástupců rodu Fissidens (sekce Fissidens a Pycnothallia) ČR a SR.Bryonora 14, 7-11. 
Kubešová, S., 2001: Bryophyte flora at lamps in public caves in the Moravian Karst (Czech Republic). Acta Musei Moraviae, Scientiae Biologicae, 86, 195202.

Kubešová, S., 2004: Mechorosty v blízkosti světel ve třech přístupných jeskyních na severní Moravě.- In: Geršl, M. (ed.) $3^{\text {rd }}$ National speleological congress, Extended abstracts, $8^{\text {th }}-10^{\text {th }}$ October 2004, Sloup. Czech Speleological Society, 41-42, Sloup.

Latzel, A., 1942: Die Grottenmoose von Postumia (Italien).- Revue Bryologique et Lichénologique, 13, 6670.

Martinčič, A., Vrhovšek, D. \& F. Batič, 1981: Flora v jamah z umetno osvetlitvijo.- Biološki Vestnik, 29, 2, 27-56.

Morton, F., 1941: Piante verti presso le lampade dell'illuminazione elettrica nelle Grotte di Postumia.Le Grotte d'Italia, Serie 2A, 4, 23-28.

Mulec, J., 2005: Algae in the karst caves of Slovenia.- PhD thesis, University of Ljubljana, Biotechnical Faculty, pp. 149.

Mulec, J., 2008: Microorganisms in hypogeon: examples from Slovenian karst caves.- Acta Carsologica, 37, 1, 153-160.

Mulec, J. \& G. Kosi, 2009: Lampenflora algae and methods of growth control.- Journal of Cave and Karst Studies, 71, 2, 109-115.
Mulec, J., Kosi, G. \& D. Vrhovšek, 2008: Characterization of cave aerophytic algal communities and effects of irradiance levels on production of pigments.- Journal of Cave and Karst Studies, 70, 1, 3-12.

Olson, R., 2002: Control of lamp flora in Mammoth cave national park.- In: Hazslinszky T. (ed.) International conference on cave lighting, Proceedings, $14^{\text {th }}-19^{\text {th }}$ November 2000, Budapest. Hungarian speleological society, 131-136, Budapest.

Rajczy, M., 1989: The flora of Hungarian caves.- Karszt és Barlang, Special Issue 1989, 69-72.

Shaw, T.R., 2003: Early electric lighting in caves - Postojnska jama, Slovenia, 1883-1929.- Acta Carsologica, 32, 1, 189-204.

Vaněčková, L., 1978: Příspěvek k výzkumu flóry některých moravských jeskyní.- Speleologický Věstník, $78,10,11-21$.

Zelinka, J., Hebelka, J., Fillo, M. \& J. Novomeský, 2002: Illumination reconstruction in Slovakian show caves in relation to "lampenflora" creation prevention.In: Hazslinszky T. (ed.) International conference on cave lighting, Proceedings, $14^{\text {th }}-19^{\text {th }}$ November 2000, Budapest. Hungarian speleological society, 151-157, Budapest. 